\title{
LANDSLIDE HAZARD ANALYSIS - A CASE STUDY IN KERASIA VILLAGE (PREFECTURE OF KARDITSA)
}

\section{Matziaris V. ${ }^{1}$, Ferentinou M. ${ }^{1}$, Angelopoulou O. ${ }^{1}$, Karanasiou S. ${ }^{1}$, and Sakellariou M. ${ }^{1}$}

${ }^{1}$ National Technical University of Athens, Faculty of Rural and Surveying Engineering, Department of Infrastructure and Rural Development Laboratory of Structural Mechanics and Engineering Structures,vmatziar@mail.ntua.gr,mferen@mail.ntua.gr,mgsakel@mail.ntua.gr

\begin{abstract}
Landslides are common phenomena in almost every part of the world. In Greece, there are many areas which suffer from landslides resulting mostly in damages to infrastructures and rarely in fatalities. Using GIS tools, one can perform stability analysis using infinite slope model, either in large or in medium scale, depending on the demands of the specific study. The proposed tool is the Landslide Hazard Analysis (LHA) which enables the user to run a stability analysis under circular, plane, or wedge failure in an area by taking into account the geomorphological, hydrological, geological and geotechnical conditions. In this paper, a problematic area was selected in Kerasia village in Karditsa district, in central Greece in order to determine slope stability. Back analysis using a limit equilibrium method prior to the GIS analysis was important so as to determine the shear strength parameters of the soil slopes. Implementing these data in LHA, a landslide hazard map was derived indicating high hazard areas. For these areas, further analysis could be performed so as to determine the status of stability more precisely and also to examine possible effects of rainfall, using more sophisticated models.
\end{abstract}

Key words: GIS, slope stability, Landslide Hazard maps.

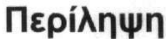

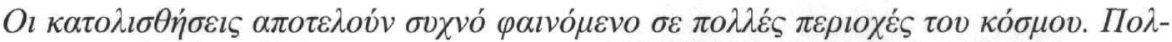

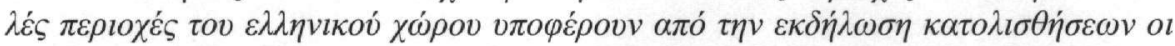

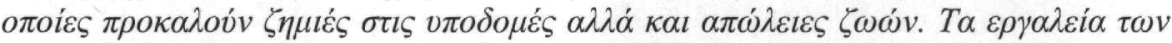

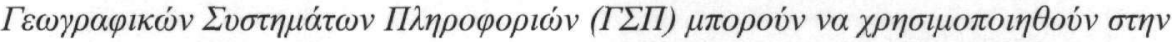

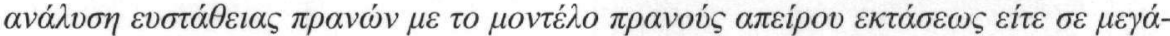

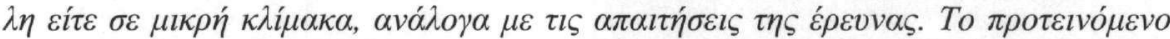

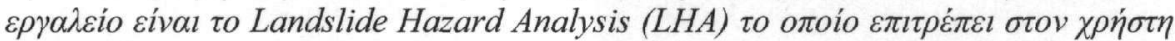

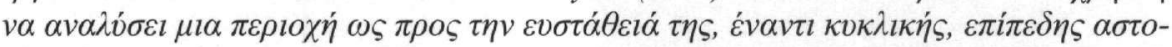

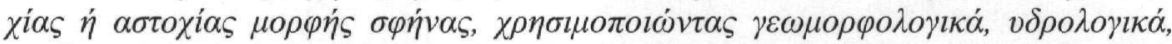

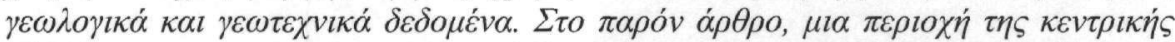

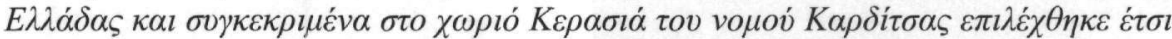

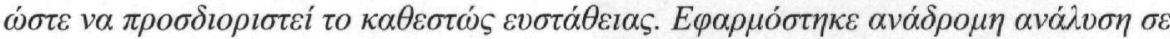

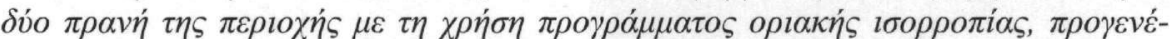

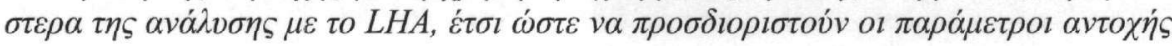




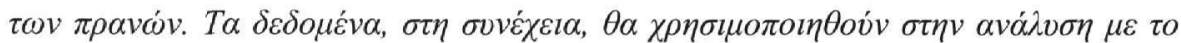

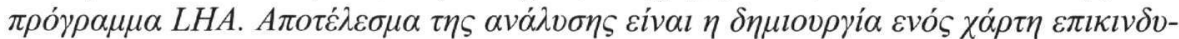

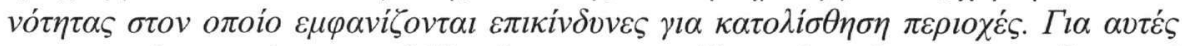

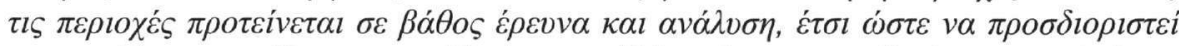

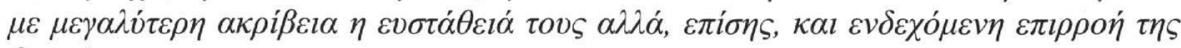

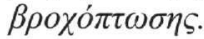

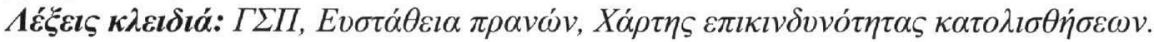

\section{Introduction}

Natural disasters are very important threats for the actual and developing societies. "Natural Disaster" is meant to be the combination of natural hazards (a physical event) and human activity. Human vulnerability, caused by the lack of appropriate emergency management, leads to financial, structural, and human losses. The resulting loss depends on the capacity of the population to support or resist the disaster, i.e. their resilience. The degree of potential loss can, also, depend on the nature of the hazard itself. A natural hazard is an event that has an effect on people, resulting from the natural processes in the environment.

Landslides are among the natural hazards which, in many cases, have caused natural disasters. According to Cruden (1991), landslide is defined as the movement of a mass of rock, debris or earth down a slope. They have several causes, including geological, morphological, physical, and human, but only one trigger (Varnes 1978). Triggering factors might be rainfalls, earthquakes, individual human activities (loading through constructions on a slope etc).

In Greece there is a great number of registered but also unregistered landslides. According to Koukis (1992), landslides are fairly common in Greece, but most of them are quite small or shallow. However, a large number of villages have been relocated due to landslide events in the last 30 years. There are, also, considerable damages to roads and other constructions caused by landslide events. Over $80 \%$ of landslides occur in the western and central parts of Greece, because of the combination of relief, rainfall and geological conditions (Koukis et al. 2005) (Fig. 1).

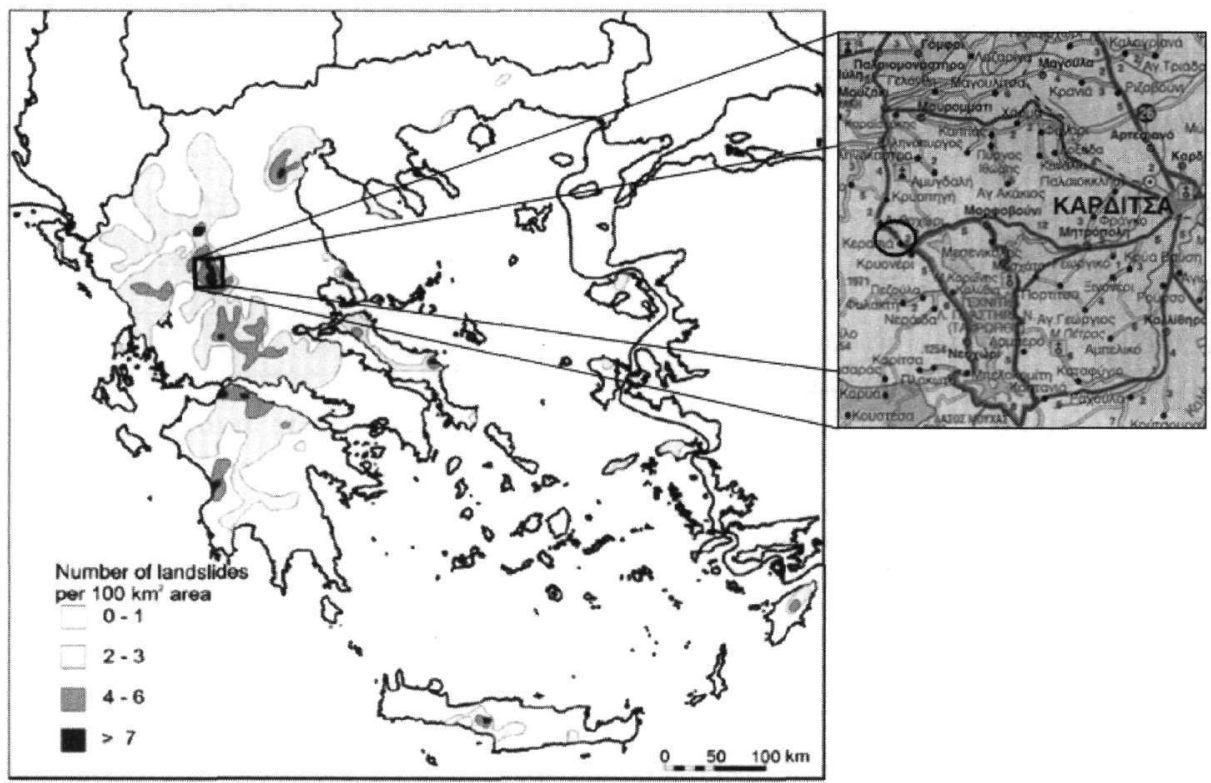

Figure 1 - Landslide hazard zonation map of Greece (Koukis et al., 2005). The study area is located in central Greece (prefecture of Karditsa) and has been indicated by the black box 


\section{Landslides and Geographical Information Systems (GIS)}

\subsection{The role of GIS in slope stability analysis}

Computer based tools, such as geoinformation systems and decision support systems, are expected to be very helpful in achieving natural hazard and risk zonation mapping (Deketh et al. 1997). One of the significant tools for this purpose is GIS.

GIS tools help us to organize spatial data, visualize complex spatial relationships of a particular location, make spatial queries about the characteristics of a particular location, combine datasets from different sources, analyze the data inferring meaning and make predictions by combining data layers according to purposely embodied rules (Bonham-Carter 1997).

Hazard mapping related to slope stability is a useful application of the above potentialities of GIS. During the last decade, the large diffusion of GIS, allowed several attempts at landslide hazard zonation over large areas using simplified geotechnical models, which were previously used for only single slope calculation (Van Western et al. 1993, Luzi and Pergalani 1996, Jibson et al. 1998, 2000, Sakellariou and Ferentinou 2001).

One of the main advantages that GIS offer is the development of hazard occurrence models, permitting evaluation of results and adjusting the input variables. The data required in the spatial analysis with GIS may include information on lithology, structure and geomorphology, and earthquake parameters. These systems allow management of large amounts of data, and support the zonation of large territories, but they are not panacea. In fact, the generalisation of terrain properties over large areas can lead to stability evaluation errors. Such errors are acceptable if they are used at screening level, to identify areas that require more detailed study.

\subsection{Landslide Hazard Analysis (LHA) Tool}

In the current paper we used Landslide Hazard Analysis Tool developed in the Laboratory of Structural Mechanics in order to create a landslide hazard assessment map for a study area seriously suffering from landslide events. This tool was developed in ArcGIS environment (Arc/Info Workstation, ArcMap, AcScene) by (Ferentinou 2004, Charalambous, 2006) (Fig. 2). On the following sections the capabilities of the implemented computational tools used in examining the problem of slope stability will be described.

The methods of slope stability analysis are based on the hypothesis of a certain failure mode. The slope under study could fail under various failure mechanisms. Soil slopes, or highly weathered rock slopes usually fail under a circular failure mode

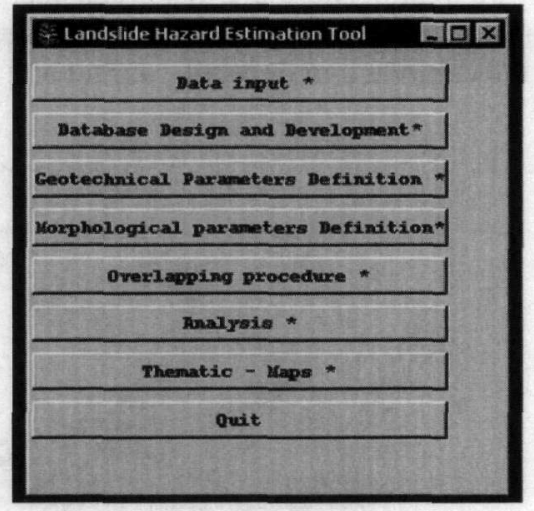

Figure 2 - The main menu of the tool "Landslide hazard estimation Tool". while rock slopes usually fail under planar or wedge failure mode. In the current tool we have integrated planar, circular and wedge failure criteria, in order to estimate landslide hazard in an entire study area.

\section{Study area}

The selected area is located in central Greece and particular in the prefecture of Karditsa. The village near the study area is called Kerasia and is included in the villages which are circumferential to the "Plastira" lake. 
For the purposes of the current research, site investigation in the study area took place in order to examine the site specific engineering geological conditions and locate recent landslides. Two active landslides were identified (Figs 3,4).

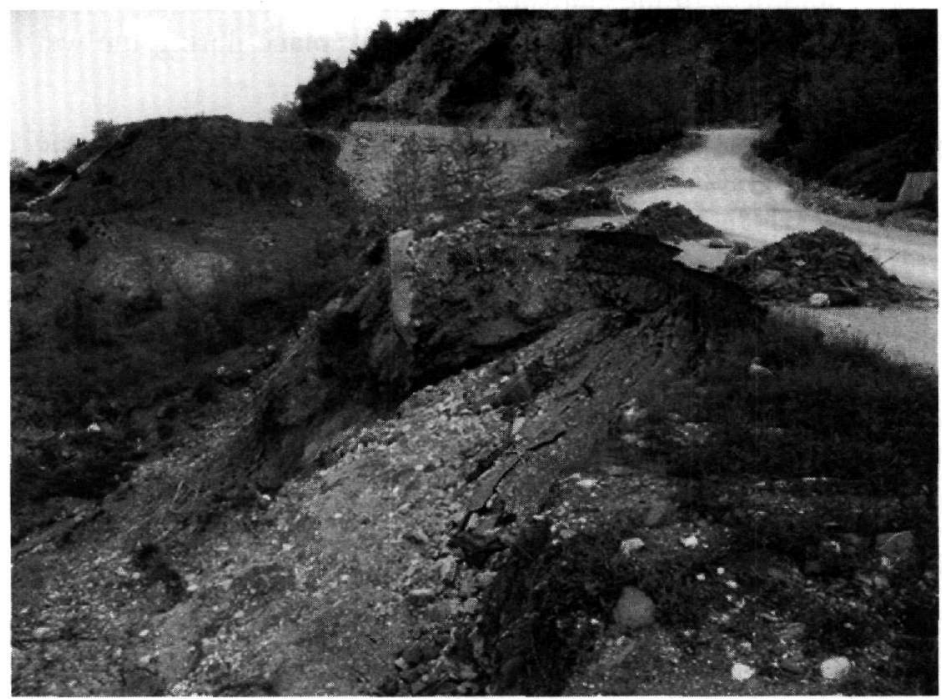

Figure 3 - Landslide No1 (cross-section AA')

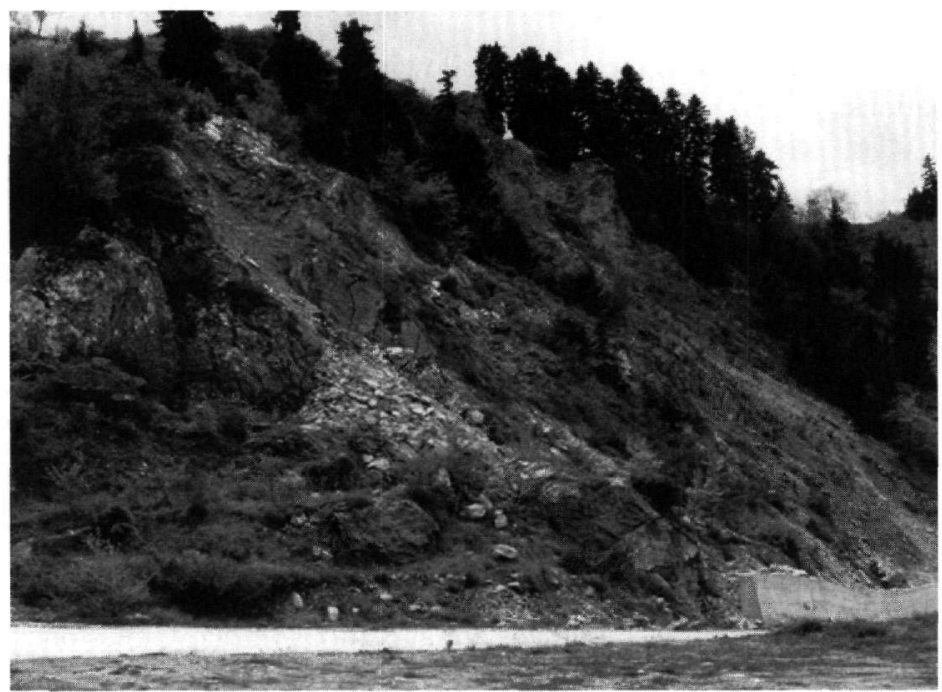

Figure 4 - Landslide No2 (cross-section BB')

A survey of the two landslides (Fig. 5) was conducted using the Topcon pulse total station GPT 7003 of $10 \mathrm{cc}$ precision. Two stations were established on the wider area and the nearest points were aimed using a prism, while the inaccessible ones with a laser beam within a range of $250 \mathrm{~m}$. The coordinates of the stations and consequently of all other points were computed in the Greek Geodetic Reference System 87 (GGRS 87).

\subsection{History of landslide phenomena in the area}

During the last century, due to the occurrence of many landslide events, a number of studies took place in the area. Particularly, the Institute of Geology and Mineral Exploration of Greece conducted these studies, in order to propose appropriate remedial measures and relieve the village 
from potential landslide hazard. The problems related to slope instability phenomena concern damages in houses, schools and the road network of the area as well as in other infrastructures. In particular, damages on the road network are very important as this is used by inhabitants and tourists. Next is a brief summary of the landslide phenomena in the area, as well as some proposals that have been made by experts. Most of the events took place during the wet season, and they were triggered by intense and prolonged precipitation.

According to Pyrgiotis (2003), the first landslides which were reported in the area occurred in 1907 and 1920. In a report, published by the IGME in 1929, proposed the transfer of the village Kerasia in another place which would be less susceptible to the occurrence of landslides. From 1929 until 1946, there was a sufficient number of landslides which caused damages in, almost, all houses of the village. In 1950, after a landslide event, there was no house in the area without damages. In another report published by IGME in 1972, the writer insists on the relocation of the village and considers the flysch formation of the area responsible for these phenomena. All the posterior reports emphasize the importance of the foundation material which is characterized inappropriate. There was, also, the suggestion of constructing drainage systems in order to lower the water table of the local aquifers and thus, reduce the hazard of landslides during rainfall events.

\subsection{Geological regime}

According to Greek and foreign researchers (Aubouin 1959, 1965, Papanikolaou and Sideris 1979, Mountrakis 1987, Papanikolaou 1986, Katsikatsos 1992.) and also to the geological map of the area, produced by IGME (Mouzakion sheet 1993), the area belongs to the geotectonic zone of Pindos. Most of the sliding and creeping zones are related to the flysch formation and to the transition beds which are the evolution from the carbonic to the clastic sedimentation.

The geology of the study area constitutes of the following formations (Fig. 5) from the most recent to the older formations:

\section{Quaternary:}

- Sliding and creeping zones (LM): they occur mainly in the flysch and are partly tectonically controlled. They constitute the main problem of the greater number of villages of the area.

\section{Alpine bedrock - Pindos zone:}

- Flysch (fo): The flysch consists of alterations of sandstones, calcitic sandstones and shales with lenticular layers of conglomerates of various lithological composition and thickness. At its base, the sandstones are coarse-grained, compact without alterations of shales, forming banks up to 2 meters thick. Thickness can extend up to 1,000 meters, although this can not be very specific due to the intense tectonic. In the study area shale layers appear.

- Transition beds ( $\mathrm{md}$ ): the transition beds are alterations of platy limestones with sandstones and shales. The sandstones predominate in the upper members.

- Upper-cretaceous limestones (kt): these are platy with nodules and layers of white, red and black in the lower members silex, as well as thin layers of red and green shales and marls. Beds of clastic crystalline limestones occur locally into them. The platy limestones develop in beds and present conchoidal fracture, their colour being white, grey white, greenish and red at the base.

The main tectonic characteristic in the study area is strongly, related to the thrust of Olonos Pindos zone towards the west. The flysch formations are strongly folded and fractured due to this deformation phase and depict low mechanical characteristics. 


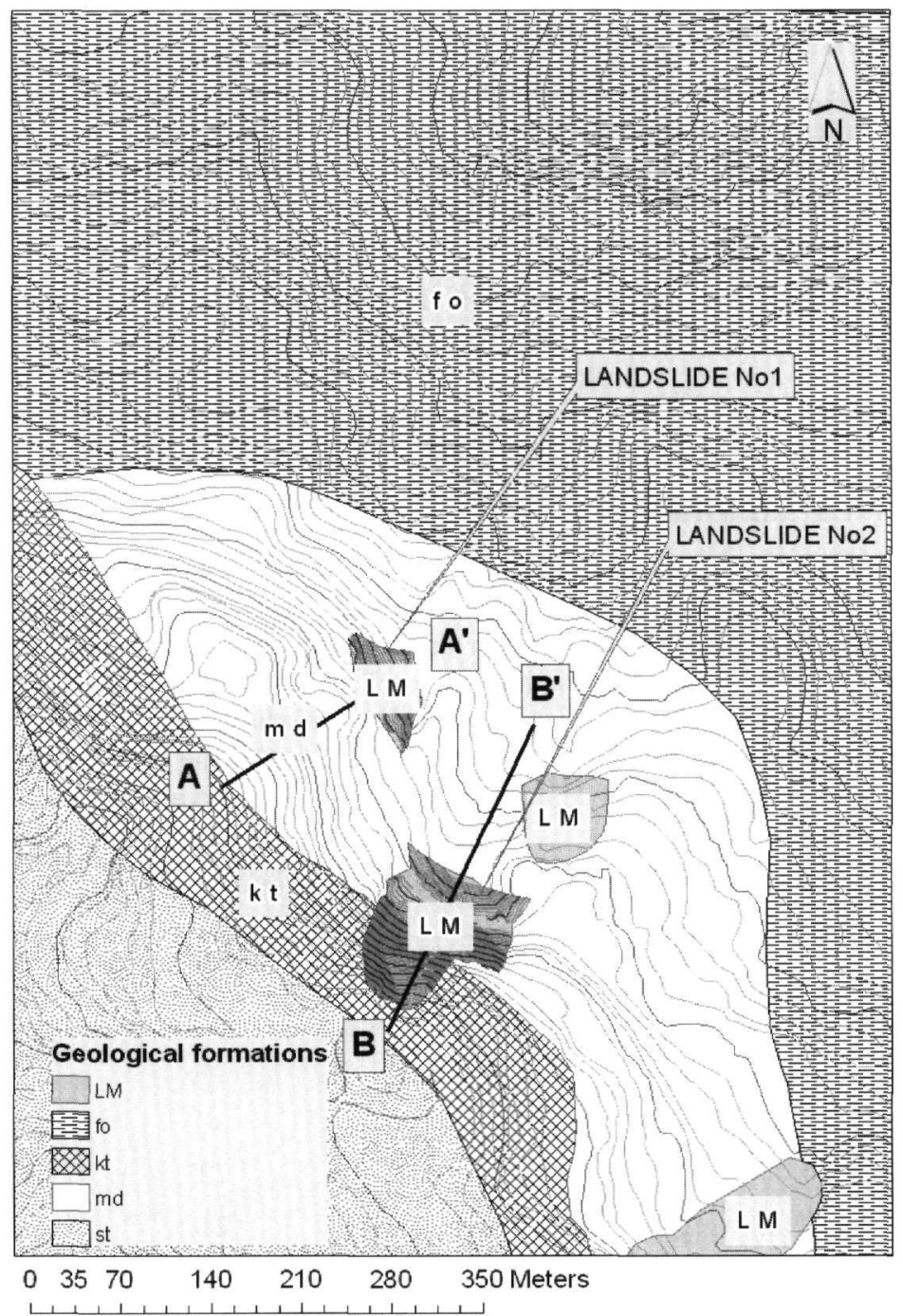

Figure 5 - Geological map of the study area. The identified landslides are indicated with the dark grey color. Also, the two cross-sections AA' and BB' are indicated

\subsection{Hydrological and hydrogeological conditions}

The area of central Greece has the highest values of annual rainfall. This is due to the mountain chain of Pindos which is responsible for the very high values of precipitation on either side. In the study area, the mean annual precipitation is about $1,000 \mathrm{~mm}$ and in some specific areas reaches $1,200 \mathrm{~mm}$. However, the rate of infiltration is too small due to the relative impermeable geological formations which lie there. Most of the precipitation runs-off through small streams and is been spilled in "Pineios" river. The study area is part of the drainage basin of "Pamissos" river.

The hydrological regime of the study area is very complex while it depends on relative permeability of the geological formations but also on their relative position in the space. However, the hydrological conditions are not favourable for the development of significant aquifers. The flysch, in general, can be considered as impermeable formation due to the presence of shales and 
other clayey rocks in great percentage. On the other hand, limestones present moderate to low permeability due to the alterations of schists, silex and marls.

The weathered beds of flysch are semi-permeable layers as well as the alluvial deposits at the places where the presence of sandy clays and deposits of mixed sands and silts is significant. However, their permeability varies, depending mainly on grain size. Coarse-grained layers have a great value of permeability while fine-grained material is, essentially, impermeable. Sandstones are considered to be permeable.

In the weathered beds there is development of shallow phreatic aquifers in which the rise of water table during winter are responsible for the occurrence of some springs. These springs have not permanent flow and do not occur during summer and autumn time. However, in the broader area there are few springs that have high discharge during the rainfall periods and are one of the reasons for the development of slope instability phenomena.

\subsection{Geotechnical conditions}

The slope stability back analysis was performed to the upper weathered zone of the transition beds where failures occur. The geotechnical properties of these beds vary because they include alterations of limestones, sandstones and shales. For the determination of the shear strength properties (i.e. cohesion $\mathrm{c}$ and angle of internal friction $\varphi$ ), Roclab software, provided by RocScience LtD, was used. In order to determine these values, we estimated the Geological Strength Index (GSI) (Marinos-Hoek 2001), the intact uniaxial compressive strength of the bedrock $\sigma_{\mathrm{c}}$, the mi value and the maximum height of the slopes, according to the in-situ observations. These estimations are presented in Table 1 .

Table 1- Estimated values of the geotechnical properties of LM formation

\begin{tabular}{ccc}
\hline Cross-section & AA' & BB' \\
\hline Un. Compressive Strength $\sigma_{\mathrm{c}}(\mathrm{MPa})$ & 3 & 4 \\
GSI & 9 & 12 \\
mi value & 8 & 10 \\
Slope Height $(\mathrm{m})$ & 22 & 75 \\
Unit weight $\gamma\left(\mathrm{kN} / \mathrm{m}^{3}\right)$ & 21 & 21
\end{tabular}

\section{Back analysis}

Prior to GIS analysis, a back analysis took place in order to get an estimation of the geotechnical properties of the formations in the area. For this reason, a limit equilibrium slope stability software was used, Slide v.5.0 provided by Rocscience LtD. The two selected cross-sections are illustrated in Figures 6 and 7.

The selection of the geotechnical properties is based on the consideration that these two slopes were at limited condition at the time of failure, something which means that the factor of safety at this time was equal or near 1 . Also, the pore pressure ratio $r_{u}$ was used in the analysis, in order to simulate rainfall conditions. The value of $r_{u}$ was selected to be 0.5 , signifying saturated conditions after rainfall events.

In cross-section $\mathrm{AA}^{\prime}$, a tension crack was taken into account, which was mapped during the site investigation. Again, this tension crack was considered to be filled with water, showing in this way critical conditions.

Slope stability analysis was performed, using Janbu method and in both cases, results can be characterized realistic. The failure surfaces actually follow the topography and also the surface 
between the weathered material and the bedrock. Moreover, the type and morphology of the failures coincide with surveyed landslide boundaries. The determined values of the geotechnical properties of the LM formation are presented in Table 2.

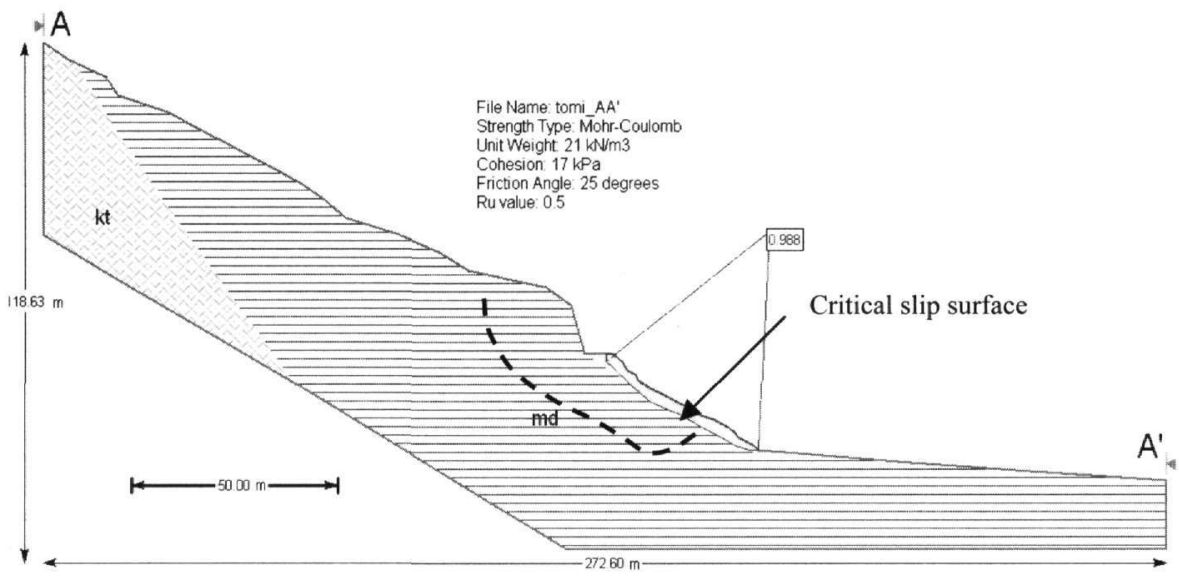

Figure 6 - Cross-section AA'

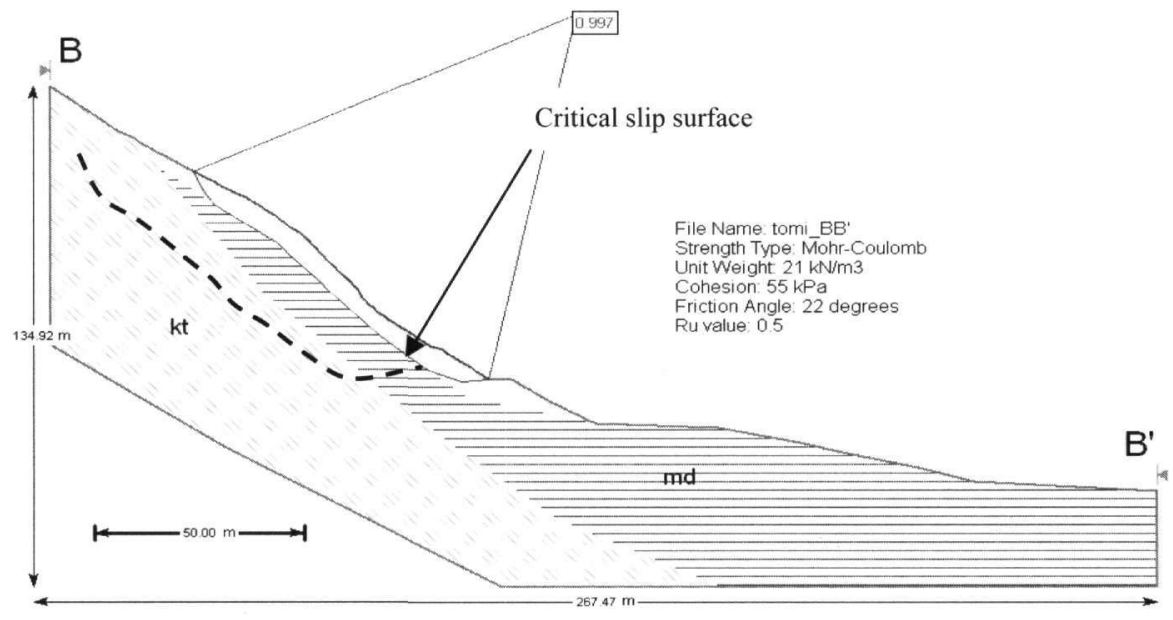

Figure 7 - Cross-section BB'

Table 2 - Estimated values of the geotechnical properties of LM formation

\begin{tabular}{ccc}
\hline Cross-section & $\boldsymbol{A} \boldsymbol{A}^{\prime}$ & $\boldsymbol{B} \boldsymbol{B}^{\boldsymbol{}}$ \\
\hline Cohesion c $(\mathrm{kPa})$ & $\mathbf{1 7}$ & $\mathbf{5 5}$ \\
Angle of internal friction $\varphi\left({ }^{\circ}\right)$ & 25 & 22
\end{tabular}

\section{GIS analysis}

\subsection{Input parameters}

The problem of slope stability is considered through the examination of the factors leading to failure occurrence. These factors are structured into appropriate thematic layers: 
Topography: is derived by processing the Digital Terrain Model (DTM). Using functions provided by ArcGIS slope angle and orientation of each slope is calculated. We used the topographic map (1:5000) of the entire area and the precise DTM produced after the surveying of the specific landslide areas.

Geologic Map: A digital geologic map forms the basis for assigning material properties throughout the area. In the current study we used the geological mapping according to IGME 2003 by Pyrgiotis.

In the case of circular failure examination, safety factor is calculated through an empirical relationship (Equation (1)). This relationship, which has been proposed by Sah et al., gives an estimation of the factor of safety as a function of slope geometry and strength parameters of the soil or the rock mass:

\section{Equation 1}

$$
F=4.32\left(\frac{c^{\prime} \cdot \operatorname{cosec} \beta}{\gamma \cdot H}\right)+1.22 \cdot\left(1-r_{u}\right) \cdot \cot \beta \cdot \tan \phi^{\prime}+0.005
$$

where $\beta$ is the angle between the slope and the horizontal plane, $H$ is the slope height, $c^{\prime}$ and $\phi^{\prime}$ are the effective values of cohesion and friction angle of the soil respectively, $\gamma$ is the unit weight, and $r_{u}$ is pore water pressure ratio. The corrected coefficients $4.32,1.22$ and 0.005 were determined by applying the least square method for a filtered data set of 49 cases of circular failure (Matziaris and Sakellariou 2005).

\subsection{Results}

From the analysis with LHA, the landslide hazard map presented in Figure 8 was developed. This map illustrates the distribution of safety factor of slopes in the examined area. There have been determined five groups of FS values, from 0.46 up to 4.15 . However, it is more important to consider three groups, i.e. slopes which have FS less than 1, these with FS between 1 and 2 and finally the slopes with FS greater than 2. Slopes which belong to the first group exhibit significant low shear strength and they are prior to instability. The area which includes these slopes is characterized as the "dangerous area", where remedial measures have to be taken in order to prevent landslide phenomena. As can be seen in the landslide hazard map, the identified landslides in the area have been indicated with grey color, showing that the factor of safety for these slopes is below or near 1. For this group of slopes, a more extended and accurate analysis is needed in order to determine the exact value of FS and to define how other factors, like rainfall and earthquake, can affect their stability.

The second group includes slopes with factor of safety between 1 and 2 . These slopes are characterized as marginally stable. For these slopes, and especially those which have FS greater than 1.4, there is no significant danger for failure and so they can be excluded from a more accurate analysis. However, if the FS is between 1 and 1.4, the impact of rainfall and earthquake in the stability of these slopes has to be determined because these factors can lead to a significant decrease of the shear strength of the soil. So, even when there seems to be safe enough, a slope can fail after an intense rainfall event or even after an earthquake. Also, it is important to determine the impact of unsaturated soil conditions, in addition to a rainfall event, as in this case there seems to be an important decrease in the shear strength of the soil, something which effects its stability (Matziaris et al. 2005). 


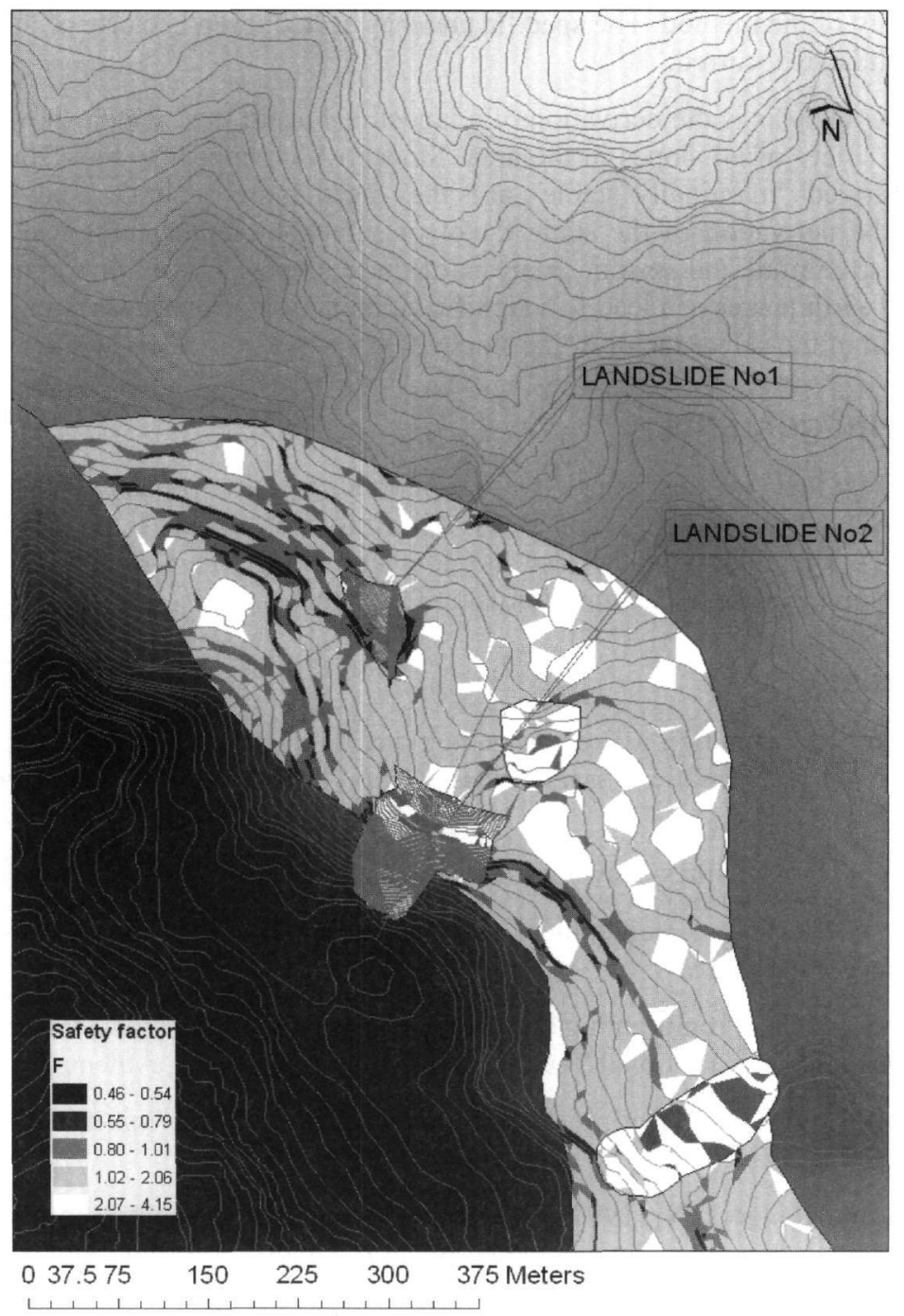

Figure 8 - "Landslide hazard map"

The results from the landslide hazard map, in Figure 8, come in deal with the map in Figure 1, which shows that the area is susceptible in landslide phenomena. A review of the landslide phenomena in the particular area was given in chapter 3.1, showing the great problem that exists there concerning slope stability. Our analysis confirms that this area faces serious instability problems, as there are slopes which are characterized unstable. The specific sites where instability problems exist are focused in the landslide hazard map and can be easily recognized. In these cases, remedial works are important in order to prevent landslide phenomena.

\section{Discussion}

A methodology for slope stability assessment, which has been developed in the laboratory of Structural Mechanics and Engineering Structures, School of Rural and Surveying Engineering in N.T.U.A., is been used in this paper. The methodology was originally presented (Sakellariou and Ferentinou 2001, Ferentinou, 2004), in order to introduce a new method for assessing slope 
stability of a study area. In the present paper, a case study in central Greece is been used in order to test the validity of the method. The specific area has been chosen because of the large number of landslides which have occurred.

The result of the analysis is the derivation of a landslide hazard map which shows the distribution of the factor of safety of all slopes in the area. Slopes which appear to have low factor of safety can be characterized "marginally stable" and they need more accurate analysis. This analysis might include the derivation of the static factor of safety, by using numerical or finite element methods, but also rainfall and seismic analysis of these slopes. This is important because factors like rainfall and earthquakes can lead to a significant reduction of the shear strength of the soil and, so, to a reduction of the safety factor of the slope.

\section{Acknowledgements}

The research reported in this paper was supported by the project PYTHAGORAS II ENVIRONMENT which is co - funded by the European Social Fund (75\%) and National Resources $(25 \%)$. The authors would also like to acknowledge the Center for the Assessment of Natural Hazards and Proactive Planning for using IT resources.

\section{References}

Aubouin, J., 1959. Contribution a l' etude geologique de la Grece Serpentrional: les confis de l' Empire et de la Thessalie, These, Science, Univ., Paris, 1958 et Ann. Geol. Pays Hellen., $10,1-525$

Aubouin, J., 1965. Geosynclines. Developments in Geotectnics, 1. Elsevier, Amsterdam, 335pp.

Bonham-Carter, G.F., 1997. “Geographical Information Systems for Geoscientists• Modeling with GIS “, Pergamon Press.

Charalambous, S., 2006, Programming the wedge failure mode and rock fall in a GIS environment, Master Thesis, National Technical University of Athens, Athens. (in Greek)

Cruden, D.M., 1991. A Simple Definition of a Landslide, Bull. of the Int. Ass. Of engineering Geology, 43, 27-29.

Deketh, H.J.R., and Rengers, N., 1997. The Role of engineering Geology in Natural Hazard Reduction for Sustainable Development, Special Lecture International Symposium of the IAEG: Engineering Geology and the Environment, Athens,v4, June 1997, Balkema /Rotterdam.

Ferentinou, M., 2004. Landslide hazard assessment using artificial neural networks in a Geographical Information System, PhD Thesis, National Technical University of Athens, Athens. (in Greek)

IGME, 1993. Mouzakion Map 1:50.000 by Karfakis I.

Jibson, R.W., Harp, E.L., and Michael, J.A., 1998. A Method for Producing Digital Probabilistic Seismic Landslide Hazard Maps: an example from the Los Angeles, California, area, US Geological Survey O-F Report, 98-113pp.

Jibson, R.W., Harp, E.L., and Michael, J.A., 2000. A method for producing seismic landslide hazard maps, Engineering Geology, 58, 271-289.

Katsikatsos, G., 1992. Geology of Greece, $O E D B$, Athens, pp. 451. (in Greek)

Koukis, G., and Ziourkas, C., 1992, Slope instability phenomena in Greece: a statistical analysis, Bulletin of the International Association of Engineering Geology, 43: 47-60. 
Koukis et al (2005), Landslide hazard Zonation in Greece, Proc. Of the first General assembly and the fourth session of representatives of the International Consortium on Landslides, October, Washington D.C, USA, Ch. 34.

Luzi L. and Pergalani, F. (1996), Application of statistical and GIS techniques to slope instability zonation. Soil Dyn. Earth. Eng., 15 (2), 83-94.

Marinos, P., Hoek E., (2001), Estimating the geotechnical properties of heterogeneous rock masses such as flysch, Bull. Eng. Geol. Env., 60:85-92.

Matziaris V., Ferentinou M., Sakellariou M., "Slope stability assessment in unsaturated soils under rainfall conditions", "International Workshop in Geoenvironment and Geotechnics (GEOENV2005)", Agioutantis \& Komnitsas (eds.), Milos 2005, pp. 91-97.

Matziaris, V. and Sakellariou, M. (2005), Modelling the effect of rainfall in unsaturated slopes, IASME TRANSACTIONS, Issue 3, Vol. 2, 442-448.

Mountrakis, D., 1987. Geology of Greece, Thessaloniki, University Publications, 257pp.

Papanikolaou, D. J. (1986), Geology of Greece, Eptalofos publ., p.p. 239.

Papanikolaou, D.J., Sideris, C. (1979), Sur la signification des zones "ultrapinduque" et "beotienne" d'epres la geologie de la region de Karditsa: l'unite de Thessalie Occidentale. Ecl. Geol.. Helv. 72/1: 251-261.

Papazachos, C., Koronaios, A., and Soldatos, T., 1997. Recent advances in upper mantle geophysical modeling. In G. Nolet, G. Christofidis and A. Filippidis (eds), Geology of the Aegean Sea. 234-258, Thessaloniki, Ziti Publications, 412pp.

Pavlidis, S., 1981. Neotectonics of Thessaly, Proc. of the XXVII IASPEI Assembly, Thessaloniki, 12-15 May, 134-152.

Pyrgiotis L., (2003), Report on the engineering geological investigation of landslide phenomena in the area of Kerasia, municipality of Plastira, prefecture of Karditsa, IGME Publ., T-2327 (in Greek).

Sah, N.K., Sheorey, P.R., Upadhyaya, L.N., Maximum likelihood Estimation of Slope Stability, Int. J. Rock Mech. Min. Sci. \& Geomech. Abstr., Vol. 31, No 1, 1994, p.p. 47-53.

Sakellariou M. and Ferentinou, M. (2001), GIS-based Estimation of Slope Stability", Natural Hazards Review, Vol 2, No1, 12-21.

Varnes, D.J., (1978), Slope movement: Types and Processes, In Scuster, R. L., and R.J. Krizek, Landslides, analysis and control: Washington D.C., Transportation Research Board Special Report 176, p. 11-33.

Van Western, C.J., Van Deuren, L., Kruse H.M.G. and Tercien, M.T.J. (1993), Geographic Information Systems in Slope Instability Zonation. ITC Publication, no. 15. 